IRA-International Journal of Management \& Social Sciences

ISSN 2455-2267; Vol.15, Issue 02 (May, 2019)

Pg. no. 36-43.

Institute of Research Advances

http://research-advances.org/index.php/RAJMSS

\title{
Inter-Regional Variations in the Process of Promoting Socio-Economic Empowerment of the Tribal Women through Self Help Groups (SHGs) Activities
}

\author{
Sundara Rao. M. ${ }^{1 \#}$, Dr Srinivasa Rao Pasala ${ }^{2}$ \\ ${ }^{1}$ ICSSR Senior Research Fellow, Center for Economic and Social Studies (CESS) Nizimai \\ Observatory Campus, Begumpet, Hyderabad-500016, India. \\ ${ }^{2}$ Assistant Professor, GVP College for Degree and P.G. Courses (A), Visakhapatnam, India.
}

\#corresponding author

Type of Work: Peer Reviewed.

DOl: http://dx.doi.org/10.21013/jmss.v15.n2.p3

\section{How to cite this paper:}

Sundara, R.M., Pasala, S.R. (2019). Inter-Regional Variations in the Process of Promoting SocioEconomic Empowerment of the Tribal Women through Self Help Groups (SHGs) Activities. IRAInternational Journal of Management \& Social Sciences (ISSN 2455-2267), 15(2), 36-43. doi:http://dx.doi.org/10.21013/jmss.v15.n2.p3

(C) Institute of Research Advances.

\section{(cc) BY-No}

This work is licensed under a Creative Commons Attribution-Non Commercial 4.0 International License subject to a proper citation to the publication source of the work.

Disclaimer: The scholarly papers as reviewed and published by the Institute of Research Advances (IRA) are the views and opinions of their respective authors and are not the views or opinions of the IRA. The IRA disclaims of any harm or loss caused due to the published content to any party.

Institute of Research Advances is an institutional publisher member of Publishers International Linking Association Inc. (PILA-CrossRef), USA. The institute is an institutional signatory to the Budapest Open Access Initiative, Hungary advocating the open access of scientific and scholarly knowledge. The Institute is a registered content provider under Open Access Initiative Protocol for Metadata Harvesting (OAI-PMH).

The journal is indexed \& included in WorldCat Discovery Service (USA), CrossRef Metadata Search (USA), WorldCat (USA), OCLC (USA), Open J-Gate (India), EZB (Germany) Scilit (Switzerland), Airiti (China), Bielefeld Academic Search Engine (BASE) of Bielefeld University, Germany, PKP Index of Simon Fraser University, Canada. 


\begin{abstract}
This study analyses that the SHGs have expanded avenues for tribal women to improve their sociodemographic and economic conditions by way of adoption of family planning methods and have awareness about promoting their health and literacy levels. On the whole, it is clear that the tribal women are able to improve control over their freedom to move and interact, leadership, and reproductive choices, to some extent. Thus there is improvement with regard to social empowerment. But, there is no improvement in power with the dimension of social empowerment. On the whole, it is clear that tribal women are able to improve control over their labour, resources, savings, credit and income and freedom to move and interact. Thus there is improvement with regard to economic power to the dimension of empowerment. However, the positive impact on their economic and living conditions is not much found in the interior hill tract villages and found in a relatively better position in the roadside villages in plain areas. From the major findings of the study, it is revealed that tribal women are able to improve control over their labour, resources, savings, credit and income, freedom to move and interact leadership, and reproductive choices. SHG approaches are influencing economic, social, and political and eventually empower the poor tribal women. The SHG activities are positively helping the poor tribal women for their comprehensive development.
\end{abstract}

Keywords: DWACRA, SHGs, Socio-Economic Empowerment, Micro Finance, Micro Enterprises.

The failure of mainstream financial institutions/agencies to serve the poor have been well-documented. Since formal finance considers the poor as risky and the small loan they demand as too expensive to administer, stringent collectable requirements have been employed which exclude a large segment of the poor population especially the rural poor women. On the part of the poor women, bank lending procedures are regarded as too cumbersome time-consuming, the transaction cost is high and credit services are ill-adapted to the native and capital needs of their microeconomic activities. For the above reasons, there is a need for the study about the strategy of Self Help Groups (SHGs) and how did microcredit help the tribal poor women to come out from the clutches of the debt trap and achieving empowerment. The development programmes are not able to provide give good status for the tribal poor women. Hence, it is important to analyze the theoretical approach of women development empowerment through Self-Help Groups approach.

The most important social innovations to help the poor in recent years have been the success of the thrift and credit based Self-Help Groups, especially those formed and operated by women. This experiment has proved to be a greater success than the government-sponsored programmes. Hence, there is a need to analyze such an innovative study which would help to know the exact of the functioning of SHGs in terms of group cohesion, dynamism, thrift and credit management, capacity building, leading to socio-economic empowerment and convergence of services. The need for rural development programmes specifically for the development of tribal women is much imperative in backward tribal regions.

\title{
Research Problem
}

As per the customary laws prevalent in all the tribal societies, except a few matriarchal societies the women are not entitled to a share within the families or ancestral property except in families where there are no male members. There are no matriarchal tribal societies in Andhra Pradesh. In view of various debilitating problems faced by the womenfolk, empowerment of tribal woman is sine-quo-non for not only improving their quality of lifestyles but also improving the conditions of tribal families and tribal villages. The exploitative traditional hierarchical relations have to be replaced by empowered local institutions.

Empowerment is the process of revitalization of local people by giving more powers and responsibilities so that they can utilize the opportunities, resources available for sustainable development. This process encompasses social, cultural, financial, skill and knowledge empowerment. Unless all these vital aspects are integrated and greater vision is developed in the local female population the sustainable development among tribals cannot be ensured. Functional literacy has to be carefully formulated to suit the changing scenario in tribal areas. Adult literacy centres separately for males and females have to be started and National level and State level targets should be fixed to bring about literacy levels of Scheduled Tribes (ST) on par with general literacy levels before the turn of the $20^{\text {th }}$ century. 
In modern times tribals are gradually alienated from their own lands, forest resources and even from their own cultural moorings. All the exploitative and disruptive forces have to be totally eliminated to restore credibility and self-reliance. In view of the fast changing scenario in tribal areas, a vision for self-reliance and urge for development has to be inculcated in tribal societies especially in the womenfolk. These vital changes can be accomplished by establishing thrift and credit societies, grain banks, MFP processing societies., Adult literacy centres. SHGs have to be established in all the settlements inhabited by tribals. These local organizations have to be empowered and guided properly in functioning and maintenance by women liaison workers and community coordinators.

A Self Help Group (SHG) is a group of about 15-20 women from a homogeneous caste or class who come together to address their common problems. They are encouraged to make a voluntary thrift on a regular basis. This savings amount, thus pooled is rotated among the members at some nominal interest rate. This process helps the members to imbibe the essentials of financial intermediation including prioritization of needs, setting norms and conditions and keeping of accounts. Banks find it easier to lend money to SHGs which have some history of credit operations and credit discipline among the members. In this way, institutional credit is made accessible to poor and helpless women.

The SHG holds power and provides strength; it can be an antidote to the helplessness of the poor women. There is great incentive to form an SHG if people feel that it is the only way to have access to institutional credit. These institutions have developed a credit delivery model that helps to attain the objectives of economic planning viz., economic and social development of women and eventually empowering women. The pilot project of linking SHGs with bank credit is an innovative programme that aims at banking with those who were considered not bankable so far. In India, the SHG approach to microcredit started in the early 90s and got momentum only since 1998-99.

In the State of Andhra Pradesh (A.P), the SHG approach started spread throughout the state since the year 2000. In the State of Andhra Pradesh, Government has taken a keen interest in spreading the message of the SHG approach and their promotion. A.P Government is implementing a project by the local vernacular name 'Velugu' (Light). Under this project, functionaries work at village, mandal, district and state levels. The functionaries at the village and mandal play an important role relating to the promotion of the SHGs and their proper functioning.

\section{Need for the Study}

The existing literature on women's empowerment is biased towards economic rather than social upliftment of women, who are weak in capabilities in the existing tribal scenario. Enhancement of capabilities of tribal women is possible only if they are less burdened with childbearing and rearing, better health, less domestic burdens for acquiring water and fuel improving the educational status. The research gap is expected to be filled by the present study which attempts to measure the impact of DWCRA on social (Education and Health) status of households a part from their economic change.

There is empirical evidence that shows any sum of the amount earned by women is entire spends for her family but in the case of men, only $30 \%$ of the earnings are allocating for his family. It indicates that whatever the amount earned by women spent on the development of the entire family rather than the male. Hence, researchers often recommend a separate income generation scheme for women to the development of the rural economy through organizing the unorganized groups called SHG. It indicates that whatever the amount earned by women spent on the development of the entire family rather than the male. Hence, the policy makers and economists recommends a separate income generation scheme for women to the development of the tribal economy through format the unorganized groups as an organized group which is called Self Help Group.

With this objective in mind, the Government of India has introduced the DWCRA Scheme with the assistance of UNICEF. An in-depth analysis of such a scheme is very essential to find out whether such a programme is contributing to women enlistment economically and socially. There is also a need to identify the loopholes in the scheme for making them operationally successful. The SHG is one of the programmes to tribal women. In Andhra Pradesh, there are research studies focusing on the impact of SHG on household income and 
living conditions of the SHGs members. However, studies comparing the performance of SHGs belonging to tribal areas are few in number. Further, studies comparing the performance of SHGs belonging to different tribal mandals of East Godavari district are also very few. The present study is an attempt in this direction.

The SHG scheme is a boon to the tribal women-folk. In the relation of SHG in East Godavari district are very few. On the other side, these studies have more gaps and not covered the determinants of income by various independents and appropriate statistical tools to analyze the study. The need for tribal development programmes specifically for the development of tribal women is much imperative in backward tribal regions. Hence an attempt is made in this study to evaluate the SHG programme in the selected mandals of Addateegala mandal of East Godavari district in general and to study the impact of the programme.

\section{Objectives and Hypothesis of the Study}

Self Help Groups strategy through microcredit is expected to be one of the major instruments for social mobilization and empowerment of tribal women in Andhra Pradesh. In this regard, East Godavari district stands on the frontline for its good performance of SHGs in the state. The present study critically analyzes the process of tribal women empowerment through SHGs strategy. Hence, an attempt is made in this study to evaluate the SHG programme in the selected villages of Addateegala mandal of East Godavari district in general and to study the impact of the programme.

This study is meant to examine the working of SHGs in tribal areas and also analyzes the efficacy of SHGs approach in empowering tribal women through microcredit system. A comparative analysis of SHGs belonging to two tribal villages within the Addateegala mandal of East Godavari district is made to know the influence of socioeconomic backwardness of the living areas of the tribes on the performance of SHGs. Finally, the comparative analysis of the performance of the SHGs belonging to two villages with different background is also attempted with a view to know the influence of the regional background on the performance and functioning of the SHGs. In this context, this study is carried out with the following objectives.

1. To assess the performance of the SHGs in the selected villages and to analyze whether there exists any difference in the implementation aspects of SHG performance across the selected villages.

2. To provide the empirical analysis relating to the socio-economic empowerment of the selected sample tribal women with special reference to the determinants of empowerment in the two selected villages.

Based on the above objectives the following hypothesis is outlined: the performance of the SHG activities as well as the important parameters relating to socio-economic empowerment may be more intensively positive in case of selected SHG members from the Bodlanka village which is with more plain and roadside area and more infrastructure, rather than the selected SHG members from the Doramamidi village which is a more interior and hill tract village and with limited extent of infrastructure.

\section{Methodology Adopted in the Study}

The study employed a multi-stage sampling technique to select the Bodlanka and Doramamidi villages of the Addateegala mandal of East Godavari district. Two villages are selected from Addateegala mandal and five SHGs are selected from each selected village (that comes to a total 10 SHGs). And then ten ST women members are selected from each selected SHG (that finally makes 100 sample SHG members). Survey technique along with personal interview method is employed for data collection.

Different statistical tools are employed for analyzing the data. Simple techniques like averages and percentages are extensively used. To assess the performance of the SHGs in the two different tribal villages An attempt is also made to use the multivariate regression model for analyzing the determinants of tribal women empowerment. Attempts are also made to measures tribal women empowerment index while taking into consideration the important socio-economic variables.

\section{Salient Features of the Study Area}

By a look at the structure of the study area, it is confined to the two selected tribal villages of the Addateegala backward mandal of the East Godavari district, it shows that a higher proportion of the area in the selected tribal villages is covered with forests and uncultivable land. The gross cropped area is limited in the 
selected villages. The analysis relating to the basic features of the Sub-Plan areas of the selected East Godavari district ultimately reveal that Addateegala mandal is having a higher extent of tribal population. With regard to several infrastructural facilities like road network, power supply, communication and banking there is a very good improvement in the roadside Bodlanka village when compared to the Doramamidi interior village. Inter regional disparities are found significantly in the study area relating to the socio-economic indicators relating to the economy of the two selected villages. The analysis also shows that the two selected villages are lagging behind on the front of different economic indicators.

\section{Performance of Self-Help Groups in the Study Area:}

All the selected SHGs from both the tribal villages have completed 3 years of functioning. In both the selected villages a considerable number of SHGs are functioning for over 5 years, it indicates sustenance of SHGs over a period of time. The analysis pertaining to saving and credit patterns of the selected SHG members reveal that the SHG model is a saving led or saving linked credit model. In this model, the members of the group mobilize their tiny savings, rotate the accumulated saving among themselves and earn some operational profit in the form of interest on money rotated. The emergence of SHG as an important link in Tribal financial system facilitating the opportunity to mobilize the small savings and at the same time meeting consumption needs of the members from the pooled savings of the group.

Thrift activity is implementing by the selected SHGs in an efficient way in the two selected villages. Each group decides the quantum of the loan amount to be sanctioned and interest to be charged. The average loan per member is estimated at Rs. 1432 in the study. It is also found that about 65 per cent of borrowings is to meet the consumption and social functions expenses. NABARD's sincere efforts to create access to tribal poor to finances of banks have contributed a lot to this SHG-Bank Linkage. The SHG-Bank Linkage is model evolved in order to improve the access of formal banking services by tribal poor. The analysis reveals that the average saving per SHG is estimated at Rs.4,283 per annum. The per SHG matching grant received is estimated at Rs.5, 283 per annum. The revolving fund of every SHG is estimated at Rs. 4,602 and the corpus fund of every selected SHG is estimated at Rs. 12,629. The total assistance per SHG is estimated around Rs. 29,775 and the average per members financial assistance is recorded at Rs. 2,052.

The analysis on determinants of current borrowings reveals that working capital expenditure requirement, consumption expenditure requirement are major determinants of current borrowings of all the SHG members. The occupational pattern of the SHG members also determine the current borrowings of the members. Recovery of the amount borrowed from group funds reveals a very encouraging picture, as more than 73 per cent of the group credit is repaid in Bodlanka village only 54 per cent recovery is recorded in Doramamidi village where the selected SHGs repayments aid amount of credit is very poor. Purpose wise classification of bank credit reveals that animal rearing absorbed a major share followed by agriculture. Coir making, coconut oil preparation, minor forest produce are the emerging economic activities for which loan is used.

Analysis of the performance of the SHGs revealed that 35 per cent of the selected SHGs in Bodlanka village and 27 per cent in Doramamidi village are very good in performance. i.e., many of the selected SHGs in both the selected villages are classified as poor performing. However, there is a significant difference in the performance of selected SHGs in both the selected tribal villages regarding the overall performance. The SHG members selected from the Bodlanka village are able to utilize the SHG activity in a more productive manner than the SHG members from the Doramamidi village.

The analysis reveals that there is no improvement in the power with the dimension of social empowerment in the study area. However, the positive impact on their socio-demographic conditions is not much found in the interior hill tract Doramamidi village and found in a relatively better position in the roadside plain Bodlanka village of Addateegala mandal. This is evident from the absence of the collective initiatives of women members to negotiate their gender, caste, class and other interests vis-à-vis institutions of the market, the state the community and family.

\section{Determinants of tribal women empowerment: an analysis of multivariate regression Analysis:}


In this study, an attempt is made to use the multivariate regression model for analyzing the determinants of tribal women empowerment. The determinants of tribal women empowerment are arrived at, using the household data collected through a standard questionnaire in East Godavari District in Andhra Pradesh. The present study has made an attempt to measures tribal women empowerment index while taking into consideration the following variables. The study has chosen seven explanatory variables for estimating their impact on tribal women empowerment, they are literacy, general health, family size, occupation, economic activity, money lending and credit, training and experience.

The regression model selected is:

$$
\mathrm{Y}_{\mathrm{e}}=\mathrm{a}+\beta_{0}+\beta_{1} \mathrm{X}_{1}+\beta_{2} \mathrm{X}_{2}+------+\beta_{7} \mathrm{X}_{7}+\mathrm{u}_{\mathrm{i}}
$$

Where

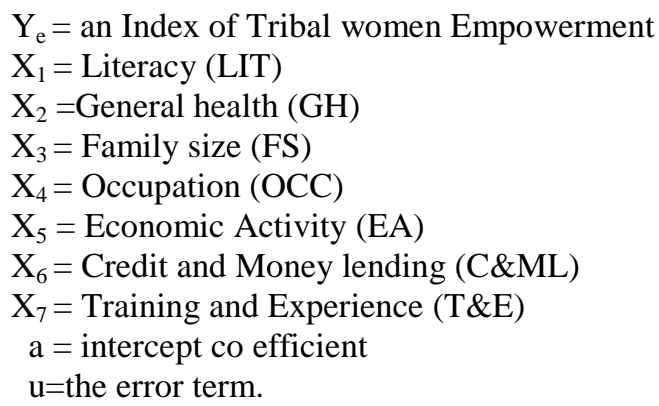

\section{A. Determinants of tribal women empowerment at the level of all the selected two villages SHG members}

In this study, an attempt is made to use the following linear regression model for estimating the impact of SHGs programme of total selected SHG members of both the selected villages with the above seven variables. Out of the seven variable, only 4 variables arrived statistical significance at some level.

The estimated equation model is given below:

$\mathrm{Y}_{\mathrm{e}}=\mathrm{a}+\beta_{0}+\beta_{1} \mathrm{X}_{1}+\beta_{4} \mathrm{X}_{4}+\beta_{5} \mathrm{X}_{5}+\beta_{7} \mathrm{X}_{7}+\mathrm{u}_{\mathrm{i}}$

The results of the estimated equation are given in the table below.

Table: 1 Determinant of Empowerment incase of all the Selected Sample SHG members

\begin{tabular}{|c|c|c|c|c|c|c|c|c|}
\hline \multirow{2}{*}{$\begin{array}{l}\text { Sl. } \\
\text { No }\end{array}$} & \multirow[b]{2}{*}{ Tribe } & \multirow[b]{2}{*}{ Intercept } & \multicolumn{4}{|c|}{ Coefficient of the independent variable } & \multirow[b]{2}{*}{$\mathbf{R}^{2}$} & \multirow[b]{2}{*}{ F value } \\
\hline & & & LIT & OCC & EA & C\&ML & & \\
\hline I & $\begin{array}{l}\text { All selected } \\
\text { SHG Members }\end{array}$ & 5.16 & $\begin{array}{l}1.36 * \\
(2.87)\end{array}$ & $\begin{array}{l}2.39 * \\
(2.72)\end{array}$ & $\begin{array}{l}1.20 * * * \\
(1.76)\end{array}$ & $\begin{array}{l}2.04^{*} \\
(3.07)\end{array}$ & 0.73 & 148.01 \\
\hline
\end{tabular}

Figure in parentheses are 't' value,

* Indicate significance at $1 \%$ level,

** indicate significant at $5 \%$ level and

*** indicate significance at 10 percent level.

From the above Table it can be noticed that out of the seven variables that are selected in model 1, in which the sample size is 100 , four variables emerge with statistical significance. The significant variables are literacy, occupation, Economic Activity and credit and money lending. Among the variable which turned with statistical significance, the coefficients of the variables literacy levels of the selected SHG members, occupational patterns of the selected sample SHG members and credit and money lending operations of the SHG members turned with statistical significance at 1 per cent level. The coefficient of the variable economic activity of the selected sample SHG members turned out with statistical significance at 10 per cent level. The explanatory variable explains 73 per cent of the variation in the dependent variable and $\mathrm{f}$ ratio $=14.01$ and statistically significant at 1 percent level.

B. Determinants of tribal women empowerment at the level of selected SHG members of Bodlanka village:

In order to measure the impact of SHG activities in case of SHG members selected from the Bodlanka 
village an attempt is made to estimate a similar liner regression model.

Regression model II pertains to SHG members selected from the Bodlanka plain village of the Addateegala mandal. Out of 7 explanatory variables, again the study found four variables that are statistically significant. The variables are $\mathrm{X}_{1}$ Literacy level of the selected sample, $\mathrm{X}_{4}$ Occupation of the SHG member households, $\mathrm{X}_{4}$ Economic Activities undertaken by the selected SHG members from the Bodlanka village and $X_{7}$ training and experience. The estimated equation model is given below:

$$
Y_{e}=a+\beta_{0}+\beta_{2} X_{2}+\beta_{3} X_{3}+\beta_{5} X_{5}+\beta_{6} X_{6}+u_{i}
$$

The results of the estimated equation are given in the table below:

Table 2 Determinants of Empowerment incase of the Selected SHG members from Bodlanka Village

\begin{tabular}{|c|c|c|c|c|c|c|c|c|}
\hline \multirow{2}{*}{$\begin{array}{l}\text { Sl. } \\
\text { No. }\end{array}$} & \multirow{2}{*}{ Village } & \multirow{2}{*}{ Intercept } & \multicolumn{4}{|c|}{ Coefficient of independent variable } & \multirow[b]{2}{*}{$\mathbf{R}^{2}$} & \multirow[b]{2}{*}{ F value } \\
\hline & & & GH & OCC & $\mathbf{E A}$ & T\&EL & & \\
\hline II & $\begin{array}{l}\text { Selected SHG Members } \\
\text { from Bodlanka }\end{array}$ & 5.23 & $\begin{array}{l}2.67 * \\
(3.36)\end{array}$ & $\begin{array}{l}3.62^{*} \\
(4.10)\end{array}$ & $\begin{array}{l}1.99 * * \\
(2.03)\end{array}$ & $\begin{array}{c}0.39 * * * \\
(1.56)\end{array}$ & 0.65 & 124.21 \\
\hline
\end{tabular}

Figure in parentheses are ' $t$ ' value,

* Indicate significance at $1 \%$ level,

** indicate significant at $5 \%$ level and

*** indicate significance at 10 percent level.

The above Table reveals that out of the seven variables that are selected in model 2 , in which four variables emerge with statistical significance. The significant variables are General Health, occupation, Economic Activity and Training and Experience. Among the variable which turned with statistical significance, the coefficients of the variables general health of the selected SHG members and occupational patterns of the selected sample SHG members turned with statistical significance at 1 per cent level. The coefficient of the variable economic activity undertaken by the SHG members of Bodlanka village are turned out with statistical significance at 5 per cent level and the coefficient of the training and experience of the members attained only 10 per cent significance. The explanatory variable explains 65 percent of the variation in the dependent variable, tribal women empowerment and $\mathrm{f}$ ratio $=124.21$ and statistically significant at 1 percent level.

\section{Determinants of tribal women empowerment at the level of selected SHG members of Doramamidi Village:}

The third equation is estimated for the empowerment of SHGs members of Doramamidi village by taking the above mentioned seven dependent variables and $\mathrm{Y}$ as the independent variable (Empowerment of SHG members of Dorasmamidi mandal).

The regression model is estimated relating to the empowerment of SHG members selected from Doramsmifi mandal and the sample size is 50 . The estimated equation model is given below:

$$
Y_{e}=a+\beta_{0}+\beta_{2} X_{2}+\beta_{3} X_{3}+\beta_{4} X_{4}+\beta_{6} X_{6}+u_{i}
$$

The results of the estimated equation are given below:

Table 3 Determinants of Empowerment in case of the Selected SHG Members from Doramamidi Mandal

\begin{tabular}{|c|c|c|c|c|c|c|c|c|}
\hline \multirow{2}{*}{$\begin{array}{c}\text { Sl. } \\
\text { No }\end{array}$} & \multirow{2}{*}{ Intercept } & \multicolumn{2}{|c|}{ Coefficient of independent variable } & \multirow{2}{*}{ F value } \\
\cline { 4 - 6 } & & GH & FS & OCC & C\&ML & \multirow{2}{*}{ R $^{2}$} & \\
\hline \multirow{2}{*}{ III } & $\begin{array}{c}\text { Selected SHG } \\
\text { Members from } \\
\text { Doramamidi }\end{array}$ & 4.77 & $\begin{array}{c}1.07^{* * *} \\
(1.67)\end{array}$ & $\begin{array}{c}1.36^{*} \\
(2.76)\end{array}$ & $\begin{array}{c}0.91^{* *} \\
(2.31)\end{array}$ & $\begin{array}{c}1.85^{* * *} \\
(1.80)\end{array}$ & 0.59 & 112.22 \\
\hline
\end{tabular}

Figure in parentheses are ' $t$ ' value,

* Indicate significance at $1 \%$ level,

** indicate significant at $5 \%$ level and

*** indicate significance at 10 percent level 
It can be noticed from the above table that, out of the seven variables that are selected for model 3 , in which four variables emerge with statistical significance. The significant variables are General Health, Family Size, Occupation, Credit and Money Lending. Among the variable which turned with statistical significance, the coefficients of the variables only the coefficient of Family Size variable turned with statistical significance at 1 per cent level. The coefficient of the variable Occupation patterns of the sample SHG members of Doramamidi village turned out with statistical significance at 5 per cent level and the coefficients of the General Health levels of the SHG members and Credit and Money Lending variables attained only 10 per cent significance. The explanatory variable explains 59 per cent of the variation in the dependent variable, and $\mathrm{f}$ ratio $=112.22$ and statistically significant at 1 per cent level.

The analysis relating to the determinants of socio-economic empowerment of the selected sample SHG members from the two different tribal villages ultimately reveals that, at the level of all members literacy levels, occupational patterns and credit and money lending emerged as the important determinants. At the level of all the SHG members selected from the Bodlanka village general health levels, occupation patterns are the important determinants. The variables economic activity and training and experience of the members are also determining the empowerment. At the level of SHG members selected from the Doramamidi village, family size variable emerged as the important determinant, occupation patterns, general health and credit money lending emerged as the other minor determinants of socio-economic empowerment of the SHG members selected from that village. The regression analysis shows that the impact of the SHGs programme is not only statistically significant but also has the highest regression coefficient, even when compared to socio-economic variables. In this study, it is found that women empowerment largely depends on the households occupation patterns, economic activity; credit and money lending, literacy and general health aspects.

\section{Conclusion}

From the major findings of the study, it is revealed that tribal women are able to improve control over their labour, resources, savings, credit and income, freedom to move and interact leadership, and reproductive choices. Thus there is an improvement to with regard to the power to the dimension of empowerment. But, there is enough improvement in the socio-demographic, economic and living conditions in case of the SHG members selected from the Bodlanka village which is having with much extent of relatively plain areas when compared to the SHG members selected from the Doramamidi village which is bestowed with interior hill tract areas. However, it is the fact that the women in interior tribal areas are able to handle some of the issues relating to their lives independently. SHG approaches are influencing economic, social, and political and eventually empower the poor tribal women. The SHG activities are positively helping the poor tribal women for their comprehensive development.

Acknowledgement: The author is very much grateful to the ICSSR authorities for permitting to utilize the data collected for the Fellowship Work.

\section{References}

[1]. Michael P.Todaro and Stephen C.Smith ( 2006) Economic Development, VIII Edition, Dorling Kindersley (India) Pvt.Ltd., New Delhi pp 27.

[2]. Janet Momsen (1991) Women and Development in the Third World, Rutledge, Newyork, p 148.

[3]. Marya Buvinic et al (1991) Women and Income in the Third World, Stanford, Calif, Stanford University Press p.41.

[4]. Haeduck Lee, The Ethnic Dimension of poverty and Income Distribution in Latin America, World Bank Washington DC (1993) AND Harry A.Patrinos "Indigenous people and poverty in Latin America", Finance and Development (March 1994): 41-43.

[5]. Bardhan Pranb and Rudra Ashok (1978) "Interlinkage of land, labour and credit relations", Economic and political weekly, vol XIII, March 16-24, p13.

[6]. Planning Commission, Government of India (2002) X Five Year Plan p 241, New Delhi, India.

[7]. Syndicate Bank ; (2003) Discussion paper No.12 October, Bangalore, India.

[8]. Bina Agarwal (1998) "Gender and command over poverty a critical gap in economic analysis and policy in South Asia" World Development Report, vol 22, pp455.

[9]. Ajay Thanka (2002) "Report on SHGs a Financial Intermediaries in India: Cost Promotion, Sustainability and Impact. 